\title{
PENGEMBANGAN MODUL PEMBELAJARAN MODEL KOOPERATIF TIPE JIGSAW PADA MATA KULIAH TATA TULIS KARYA ILMIAH DAN SEMINAR PADA PENDIDIKAN VOKASI
}

\author{
DEVELOPMENT OF LEARNING MODULE TYPE JIGSAW COOPERATIVE MODEL ON \\ COURSE OF WRITING SCIENTIFIC WORK AND SEMINAR ON VOCATIONAL EDUCATION
}

\author{
Bulkia Rahim $^{1 *}$ Junil Adri $^{1}$ dan Suparno ${ }^{1}$ \\ (1),(2),(3)Jurusan Teknik Mesin, Fakultas Teknik, Universitas Negeri Padang \\ Kampus Air Tawar, Padang 25131, Indonesia \\ bulkiarahim@gmail.com \\ juniladri@gmail.com \\ suparno121251@gmail.com
}

\begin{abstract}
Abstrak
Penelitian ini bertujuan untuk: (1) untuk menghasilkan modul pembelajaran model kooperatif Tipe jigsaw pada mata kuliah Tata Tulis Karya Ilmiah dan Seminar; (2) mengidentifikasi Validitas, Praktikalitas dan Efektifitas modul pembelajaran model kooperatif Tipejigsaw pada mata kuliah Tata Tulis Karya Ilmiah dan Seminar. Model penelitian yang digunakan adalah pengembangan IDI (Instruksional Development Institute). Dengan metode penelitian dan pengembangan (Research and Development / R\&D). Subjek penelitian adalah mahasiswa Teknik Mesin FT-UNP yang mengambil mata kuliah Tata Tulis Karya Ilmiah dan Seminar berbasis kooperatif tipe jigsaw. Jenis data yaitu data primer dimana data yang diberikan oleh dosen ahli dan mahasiswa. Instrumen pengumpul data berbentuk angket. Teknik analisis data deskriptif untuk mendeskripsikan kevalidan, kepraktisan dan keefektifan modul Tata Tulis Karya Ilmiah dan Seminar berbasis kooperatif tipe jigsaw. Berdasarkan temuan penelitian ini disimpulkan bahwa modul Tata Tulis Karya Ilmiah dan Seminar berbasis kooperatif tipe jigsaw ini valid, praktis dan efektif untuk dimanfaatkan sebagai modul pembelajaran pada mata kuliah Tata Tulis Karya Ilmiah dan Seminar.
\end{abstract}

Kata kunci :Modul, Hasil Belajar, Validitas, Praktikalitas, Efektivitas.

\begin{abstract}
This study aims to: (1) to produce a jigsaw type cooperative model learning module in the course of Writing Scientific Works and Seminars; (2) identify the validity, practicality and effectiveness of the jigsaw cooperative model learning module in the course of writing scientific papers and seminars. The research model used is the development of IDI (Instructional Development Institute). With research and development methods (Research and Development $/ R \& D$ ). The research subjects were FT-UNP Mechanical Engineering students who took the course of Scientific Writing and the jigsaw cooperative-based Seminar. This type of data is primary data where the data provided by expert lecturers and students. Data collection instruments are in the form of questionnaires. Descriptive data analysis techniques to describe validity, practicality and effectiveness of the Tata Writing Scientific Work module and the jigsaw cooperative based seminar. Based on the findings of this study, it was concluded that the Tata Writing Scientific Work module and the jigsaw cooperative based seminar was valid, practical and effective to be used as a learning module in the course of Writing Scientific Work and Seminars.

Keywords :Modules, Learning Outcomes, Validity, Practicality, Effectiveness.
\end{abstract}




\section{Pendahuluan}

Faktor pendidikan yang kurang sesuai dalam penyampaian materi dan pemilihan media pembelajaran menyebabkan tujuan pembelajaran kurang dapatditerimasecarasempurna oleh mahasiswa. Faktor pendidikan disini diartikan seperti fasilitas yang dibutuhkan dalam proses pembelajaran seperti media pembelajaran yang digunakan oleh dosen. Hal ini pentingnya pemilihan media pembelajaran merupakan bahan yang dibutuhkan oleh dosen dalam interaksi dengan mahasiswa.

Proses belajar mahasiswa dipengaruhi oleh media pembelajaran baik dikampus maupun di rumah. Umumnya mahasiswa hanyafokus belajar di kampussaja, setelahdi rumah fokus belajar mereka berkurang karena faktor lainseperti bekerja bermain dan lain-lain. Hal ini mempengaruhi proses belajar mahasiswa, pemahaman mahasiswa di dalam mendalami pembahasan pembelajaran sehingga berdampak pada hasil belajar mahasiswa. Kurangnya bahan ajar atau sumber pembelajaran merupakan salah satu bagian penyebab dari tidak maksimalnya dari pemahaman mahasiswa di dalam pembelajaran mata kuliahTata Tulis Karya Ilmiah dan Seminar. Untuk itu perlu menambah referensi dan memperbanyak bahan ajar Tata Tulis Karya Ilmiah dan Seminar untuk menunjang kemampuan mahasiswa di dalam memahami pelajaran.

Hasil dari nilaiSemester Januari-Juni 2017 yang terdapat dua seksi mata kuliah yaitu seksi 104676 dan seksi 104677, kompetensi mahasiswa yang dicapai juga masih belum maksimal seperti terlihat pada Tabel 1.1.

Tabel 1.Nilai Semester Matakuliah Tatatulis Karya Ilmiah dan Seminar Semester Januari-Juni 2017

\begin{tabular}{|c|c|c|c|c|}
\hline \multirow[b]{2}{*}{ No } & \multirow{2}{*}{$\begin{array}{c}\text { Kode Seksi } \\
\text { Interval Nilai } \\
\text { Angka }\end{array}$} & \multicolumn{3}{|c|}{ : 104676 dan 104677} \\
\hline & & $\begin{array}{c}\text { Interval } \\
\text { Nilai } \\
\text { Huruf }\end{array}$ & $\begin{array}{c}\text { Frekue } \\
\text { nsi (f) }\end{array}$ & $\begin{array}{c}\text { Persentase } \\
(\%)\end{array}$ \\
\hline 1 & $0-39$ & $\mathrm{E}$ & 5 & 8,47 \\
\hline 2 & $40-49$ & $\mathrm{D}$ & 0 & 0,00 \\
\hline 3 & $50-54$ & $\mathrm{C}-$ & 1 & 1,69 \\
\hline 4 & $55-69$ & $\mathrm{C}$ & 5 & 8,47 \\
\hline 5 & $60-64$ & $\mathrm{C}+$ & 5 & 8,47 \\
\hline 6 & $65-69$ & B- & 13 & 22,03 \\
\hline 7 & $70-74$ & $\mathrm{~B}$ & 13 & 22,03 \\
\hline 8 & $75-79$ & $\mathrm{~B}+$ & 11 & 18,64 \\
\hline 9 & $80-84$ & A- & 6 & 10,17 \\
\hline 10 & $85-100$ & $\mathrm{~A}$ & 0 & 0,00 \\
\hline \multicolumn{3}{|c|}{ Jumlah } & 59 & 100,00 \\
\hline \multicolumn{3}{|c|}{ Nilai Kecil 64, Nilai dibawah B- } & 16 & 27,12 \\
\hline \multicolumn{3}{|c|}{ Nilai Besar 65, Nilai diatas C+ } & 43 & 72,88 \\
\hline
\end{tabular}

Sumber : http://sia.unp.ac.id

Berdasarkan Tabel 1.1. dari 59 orang mahasiswa, hanya 43 orang mahasiswa $(72,88 \%)$ yang mendapat nilai $65 \mathrm{ke}$ atas atau B- ke atas. Sedangkan dari mahasiswa yang nilainya di bawah 65 terdapat 16 orangmahasiswa $(27,12 \%)$, artinya hampir sepertiga dari jumlah mahasiswa semester satu angkatan 2016 yang dibawah nilai 65dan terdapat nilai di bawah 40 atau mendapat nilai $\mathrm{E}$ sebanyak $8,47 \%$.

Media pembelajaran dapat mempertinggi kualitas proses belajar mahasiswa antara lain bahan pengajaran akan menarik perhatian mahasiswa sehingga dapat menumbuhkan motivasi belajar mahasiswa. Hal ini sangat penting bagi dosenuntuk memilih media pembelajaran yangdigunakan.Pemilihan media pembelajaran yang kurang sesuai menyebabkan mahasiswa cepat bosan, tidak mendengarkan dosen sehingga mahasiswa kurang menyukai matapelajaran tersebut. Hal ini berpengaruhpada hasil belajar mahasiswa dan motivasi belajar mahasiswa.

Modul pada mata kuliah Tata Tulis Karya Ilmiah dan Seminar ini belum ada sebelumnya. Jurusan Teknik Mesin hanya terdapat Perangkat pembelajaran Tata Tulis Karya Ilmiah dan Seminar dan berbagai macam buku tentang Tata Tulis Karya Ilmiah dan Seminar yang ada di perpustakaan Jurusan Teknik Mesin. Hal ini membuat mahasiswa kurang belajar mandiri yang hanya mengandalkan penjelasan dari dosen, buku dan dari layanan internet.

Berbagai macam-macam buku Tata Tulis Karya Ilmiah dan Seminar yang ada di perpustakaan memiliki kelebihan yaitu membahas dalam ruang lingkup yang luas, terinci, terstruktur dan terarah. Tetapi di dalam buku tidak tersedianya pedoman, tidak adanya lembaran kegiatan mahasiswa, tidak adanya lembaran kerja, tidak adanya kunci lembaran kerja, tidak adanya lembaran tes, tidak adanya kunci lembaran tes pembelajaran. Hal ini tidak dapat dilihat tingkat pemahaman mahasiswa di dalam materi pembelajaran matakuliah Tata Tulis Karya Ilmiah dan Seminar.

Mengatasi permasalahan tersebut di atas maka perlunya menambah referensi di dalam pembelajaran mahasiswa seperti modul sebagai media pembelajaran. Modul memiliki kelebihan-kelebihan untuk pembelajaran karena di dalam modul terdiri dari: 1). Pedoman, berisi petunjuk-petunjuk agar mengajar secara efisien serta memberikan penjelasan tentang jenis-jenis kegiatan yang harus dilakukan oleh mahasiswa, waktu untuk menyelesaikan modul, alat-alat pelajaran yang harus dipergunakan. 2). Lembarankegiatan mahasiswa, adanya pembahasan materi sesuai dengan tujuan 
instruksional yang akan dicapai seperti keselamatan kerja mahasiswa di dalam pratikum, materi setiap perkuliahan sehingga membantu mahasiswa di dalam pembelajaran. 3). Lembaran kerja, menyertai lembaran kegiatan mahasiswa yang digunakan untuk menjawab atau mengerjakan soal-soal tugas atau masalah-masalah yang harus dipecahkan. 4). Kunci lembaran kerja. 5). Lembaran tes. 6). Kunci lembaran tes. Sehingga dengan terstukturnya pembelajaran baik materi maupun langkah kerja mahasiswa di dalam modul maka di harapkan akan membawa dampak terhadap pemahaman mahasiswa di dalam pembelajaran. Maka modul sangat penting di dalam pembelajaran.

Permasalahan yang terjadi yang berkaitan dengan media pembelajaran diupayakan untuk mencoba mengembangkan sebuah media berbentuk modul mata kuliah Tata Tulis Karya Ilmiah dan Seminar. Sudah adanya perangkat pembelajaran Tata Tulis Karya Ilmiah dan Seminar, buku Tata Tulis Karya Ilmiah dan Seminar di Jurusan Teknik Mesin Fakultas Teknik Universitas Negeri Padangmaka perlu dilakukannya pengembangan berbentuk modul.

Modul mata kuliah Tata Tulis Karya Ilmiah dan Seminarini diharapkan mahasiswa dapat belajar mandiri dan lebih semangat karena modulTata Tulis Karya Ilmiah dan Seminar ini memberi fasilitas kepada mahasiswa untuk mengulangi bagian-bagian yang penting untuk dipelajari, dilengkapi gambar dan sistematikanya disusun secara runtut dengan bahasa yang sederhana dan jelas. oleh sebab itulah perlu diadakan penelitian.

\section{II.Studi Pustaka}

\section{A. Hasil Belajar}

Belajar merupakan suatu proses perubahan dan interaksi dengan lingkungan untuk memenuhi kebutuhan fisik, mental dan spiritual. Perubahan tersebut mencakup aspek tingkah laku, keterampilan dan pengetahuan. Menurut Gagne dalam Sagala (2003:13) dijelaskan bahwa: "Belajar adalah sebagai suatu proses dimana suatu organisma berubah perilakunya sebagai akibat dari pengalaman". Selanjutnya Benny (2009: 6) menjelaskan bahwa "belajar adalah kegiatan yang dilakukan oleh seseorang agar memiliki kompetensi berupa keterampilan dan pengetahuan yang diperlukan".

Hasil belajar menjadi tolok ukur yang dapat digunakan untuk menentukan tingkat keberhasilan mahasiswa dalam menguasai materi pelajaran. Hasil belajar juga diartikan sebagai kemampuan kognitif, afektif dan psikomotorik yang dimiliki mahasiswa setelah mengikuti proses belajar mengajar.

\section{B. ModulPembelajaran}

Modul merupakan suatu alat atau sarana pembelajaran yang di dalamnya berupa materi, metode dan evaluasi yang dibuat secara sistematis dan terstruktur sebagai upaya untuk mencapai tujuan kompetensi yang diharapkan modul dirancang secara khusus dan jelas berdasarkan kecepatan pemahaman masing-masing mahasiswa, sehingga mendorong mahasiswa untuk belajar sesuai dengan kemampuanya. Nasution (2003:205), mengemukakan modul dapat dirumuskan sebagai: suatu unit yang lengkap yang berdiri sendiri dan terdiri atas suatu rangkaian kegiatan belajar yang disusun untuk membantu mahasiswa mencapai sejumlah tujuan yang dirumuskan secara khusus dan jelas.

\section{KeuntunganModul}

Menurut E. Mulyasa (2005: 43) "tujuan utama dari modul adalah meningkatkan efisien dan efektifitas pembelajaran, baik waktu, dana, fasilitas, maupun tenaga guna mencapai tujuan secara optimal". Tujuan pengajaran modul bagi peserta didik menurut S. Nasution (2005: 205) antara lain:

1. Membuka kesempatan bagi peserta didik untuk belajar menurut kecepatan masing-masing.

2. Memberikesempatan bagi peserta didik untuk belajar menurut cara masing-masing, tergantung pada latar belakang pengetahuan dan kebiasaan belajar masing-masing peserta didik.

3. Memberi pilihan dari sejumlah besar topik dalam suatu mata pelajaranatau bidang studi tertentu pada peserta didik yang tidak mempunyai minat yang sama atau motivasi yang sama untuk mencapai tujuan yang sama.

4. Memberi kesempatan kepada peserta didik untuk mengenal kelebihan dan kekurangannya serta memperbaiki kelemahan masing-masing peserta didik melalui ulangan-ulangan atau variasi dalam cara belajar

Modul mempunyai beberapa keuntungan sebagai media pembelajaran antara lain penguasaan, menambah motivasimahasiswa untuk belajar sendiri, mengatasi keterbatasan waktu, ruang, serta daya indera baik mahasiswa maupun dosen serta mengetahui kemampuan masing-masing mahasiswa. 


\section{Pembelajaran Tata Tulis Karya Ilmiah dan Seminar}

Pembelajaran tata tulis karya ilmiah danseminar berisi materi tentang mengidentifikasi ruang lingkup tata tulis karya ilmiah dan seminar, menjelaskan pengertian karya ilmiah, menjelaskan syarat menulis karya ilmiah, menjelaskan jenis dan bentuk karya ilmiah, mengidentifikasi langkah-langkah pengumpulan dan penyusunan bahan tulis, mengidentifikasi tahap penyusunan karya ilmiah, menjelaskan cara-cara menulis esai, menjelaskan tata cara menulis karya ilmiah popular, menjelaskan tata cara menulis artikel untuk jurnal ilmiah, menjelaskan tata cara penulisan makalah, menjelaskan tata cara penulisan resensi, proposal penelitian, laporan hasil penelitian, skripsi, membuat dan menampilkan pembelajaran bermedia.

\section{E. Pembelajaran Menggunakan Modul}

Pembelajaran menggunakan modul, peserta didik dapat tiga sumber, yaitu pertama dari mahasiswa,dosen dan modul yang sudah ada. Jadi pembelajaran menggunakan modul yaitu berpusat pada mahasiswa dan di dukung oleh penggunaan modul pembelajaran serta ditegaskan pembelajaran oleh dosen. Apabila peserta didik lupa tentang materi bisa mempelajari dari modul yang ada. Artinya pembelajaran dengan modul peserta didik bisa belajar atau dapat pembelajaran dari mahasiawa,dosen dan dari modul.

\section{F. Pembelajaran Konvensional}

Menurut Djamarah (1996), Metode pembelajaran konvensional adalah metode pembelajaran tradisional atau disebut juga dengan metode ceramah, karena sejak dulu metode ini telah dipergunakan sebagai alat komunikasi lisan antara dosen dengan anak didik dalam proses belajar dan pembelajaran. Dalam pembelajaran sejarah metode konvensional ditandai dengan ceramah yang diiringi dengan penjelasan serta pembagian tugas dan latihan.

\section{G. Pembelajaran Model Jigsaw}

Pembelajaran kooperatif Jigsaw merupakan salah satu model pembelajaran kooperatif yang mendorong mahasiswa aktif dan saling membantu dalam menguasai materi pelajaran untuk mencapai prestasi yang maksimal.Seperti diungkapkan oleh Lie (1999:73) bahwa, "Pembelajaran kooperatif model Jigsaw ini merupakan model pembelajaran kooperatif dengan cara siswa belajar dalam kelompok kecil yang terdiri dari empat sampai enam orang secara heterogen dan siswa bekerja sama saling ketergantungan positif dan bertanggungjawab secara mandiri”.

Model pembelajaran kooperatif model Jigsaw ini mahasiswa memiliki banyak kesempatan untuk mengemukakan pendapat dan mengolah informasi yang didapat dan dapat meningkatkan keterampilan berkomunikasi, anggota kelompok bertanggungjawab terhadap keberhasilan kelompoknya dan ketuntasan bagian materi yang dipelajari dan dapat menyampaikan informasinya kepada kelompok lain.

Mengoptimalkan manfaat belajar kelompok, keanggotaan kelompok heterogen, baik dan segi kemampuannya maupun karakteristik lainnya, dengan demikian, cara yang efektif untuk menjamin heterogenitas kelompok ini adalah dosen membuat kelompok-kelompok itu. Jika mahasiswa dibebaskan membuat kelompok sendiri maka biasanya mahasiswa akan memilih teman-teman yang sangat disukainya misalnya sesama jenis, sesama etnik dan sama dalam kemampuan.

Hal ini cenderung menghasilkan kelompok-kelompok yang homogen dan seringkali mahasiswa tertentu tidak masuk dalam kelompok manapun. Oleh karena itu, memberikan kebebasan mahasiswa untuk membentuk kelompok sendiri bukanlah cara yang baik, kecuali dosen membuat batasan tertentu sehingga dapat menghasilkan kelompok yang heterogen. Pengelompokkan secara acak juga dapat digunakan, khusus jika pengelompokkan itu terjadi pada awal tahun ajaran baru dimana dosen baru sedikit mempunyai informasi tentang mahasiswa-mahasiswanya.

Hubungan antara kelompok asal dan kelompok ahli digambarkan sebagai berikut, (Arends, 1997)

\section{Kelompok Asal}

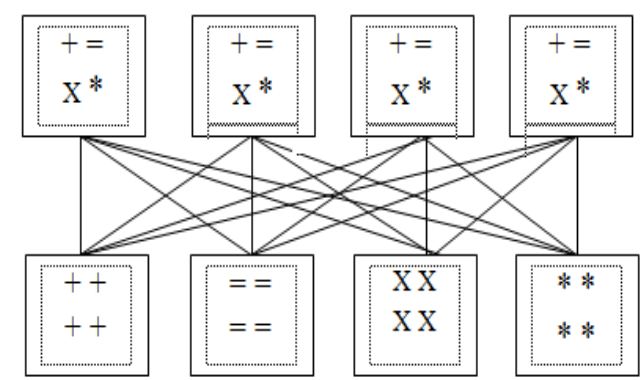

Kelompok Ahli

Gambar 1. Ilustrasi Kelompok Jigsaw 


\section{III.Metode}

Penelitian ini menggunakan metode penelitian dan pengembangan (Research and Development). Penelitian pengembangan adalah metode penelitian yang digunakan untuk menghasilkan produk tertentu dan menguji keefektifan produk tersebut(Sugiyono.

pengembanganmodul pembelajaran ini menggunakan model IDI(Instruksional Development Institute). Model IDI menetapkan prinsip-prinsip pendekatan sistem yang meliputi tiga tahap yaitu define, develop, dan evaluate(Tortora, G.R. and rabowski,S.H.,2003).

Teknik pengumpulan data berupa angket (kuesioner). Teknik analisis data terdiri dari analisis validitas, analisis praktikalitas dan analisis efektifitas. Analisis validitas adalah hasil validasi melalui angket terhadap Tata Tulis Karya Ilmiah dan Seminar Berbasis Kooperatif Tipe Jigsaw dari validator terhadap seluruh aspek (materi, format dan penyajian) yang dinilai. Analisis praktikalitas diperoleh dari hasil penilaian melalui angket terhadap Tata Tulis Karya Ilmiah dan Seminar Berbasis Kooperatif Tipe Jigsaw dari dosen dan mahasiswa. Analisis efektivitas dari Tata Tulis Karya Ilmiah dan Seminar Berbasis Kooperatif Tipe Jigsawditentukan dengan cara melihat pencapaian ketuntasan hasil belajar siswa dengan menggunakan Tata Tulis Karya Ilmiah dan Seminar Berbasis Kooperatif Tipe Jigsaw yang diperoleh saat penelitian dan dibandingkan dengan sebelum menggunakan Tata Tulis Karya Ilmiah dan Seminar Berbasis Kooperatif Tipe Jigsaw.

\section{IV.Hasil dan Pembahasan}

Penelitian ini menghasilkan suatu produk modul Tata Tulis Karya Ilmiah dan Seminar berbasis kooperatif tipe jigsaw. Adapun rincian modul Tata Tulis Karya Ilmiah dan Seminar berbasis kooperatif tipe jigsaw yang dihasilkan adalah terdiri atas komponen-komponen sebagai berikut:

1. Modul Tata Tulis Karya Ilmiah dan Seminar berbasis kooperatif tipe jigsaw terdiri dari modul kegiatan kuliah 1. Tentang mengidentifikasi ruang lingkup tata tulis karya ilmiah dan seminar, kegiatan kuliah 2. Tentang pengertian karya ilmiah, kegiatan kuliah 3 . Tentang syarat menulis karya ilmiah, kegiatan kuliah 4. Tentang jenis dan bentuk karya ilmiah, kegiatan kuliah 5. Tentang langkah-langkah pengumpulan dan penyusunan bahan tulis, kegiatan kuliah 6 . Tentang tahap penyusunan karya ilmiah, kegiatan kuliah 7. Tentang menulis esai, kegiatan kuliah 8. Tentang menjelaskan tata cara menulis karya ilmiah popular, kegiatan kuliah 9.Tentang tata cara menulis artikel, kegiatan kuliah 10. Tentang tata cara penulisan makalah, kegiatan kuliah 11. Tentang tata cara penulisan resensi, kegiatan kuliah 12 . Tentang proposal penelitian, kegiatan kuliah 13. Tentang laporan hasil penelitian, kegiatan kuliah 14. Tentang laporan hasil penelitian

2. Modul kegiatan kuliah 1sampai kegiatan kuliah 8 mempunyai 14 kegiatan kuliah. Masing-masingkegiatan kuliah terdiri dari indikator tujuan kegiatan perkuliahan, uraian materi, rangkuman, tes formatif, soal latihan, lembaran kerja mahasiswa dan jawaban tes formatif.

3. Latihan pada setiap kegiatan kuliah terdiri atas latihan tes formatif dengan jumlah soal sebanyak 5 butir untuk soal objebtif dan 5 butir soal essay.

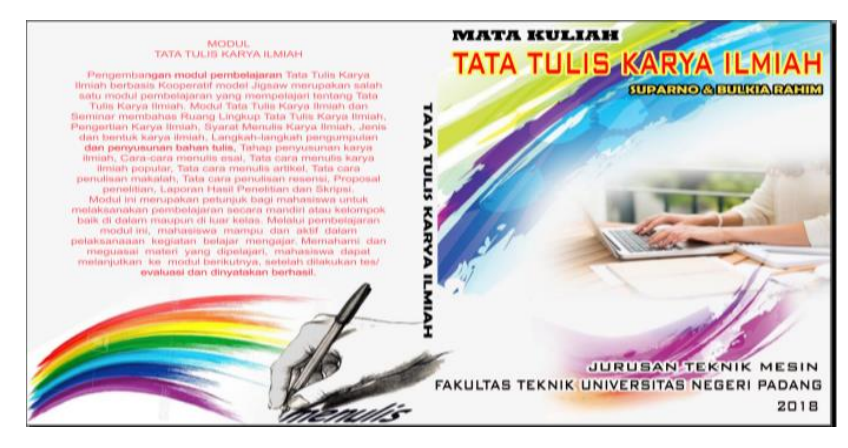

Gambar 2. Tampilan Cover Depan dan Belakang Modul Tata Tulis Karya Ilmiah dan Seminar Berbasis Kooperatif Tipe Jigsaw

\section{Data Uji Validitas}

Pengambilan data validitas modul Tata Tulis Karya Ilmiah dan Seminar Berbasis Kooperatif Tipe Jigsawsebagai modul pembelajaran adalah dengan menggunakan angket (kuesioner). Dalam hal ini peneliti memberikan angket kepada tiga orang validator yang memvalidasi modul yang dikembangkan. Validator pertama, ke dua, ke tiga, validasi serta penilaian terhadap materi, validasi terhadap format dan penyajian pada modul yang dikembangkan.

Hasil penilaian dari masing-masing aspek indikator yang diberikan validator dijumlahkan dan dihitung persentase penilaian menurut aspek yang telah dibuat. Berikut deskripsi data yang didapat pada penelitian ini:

\section{a. Data Uji Validasi Isi/Materi}


Penilaian validator tentang kevalidan isi/materi modul Tata Tulis Karya Ilmiah dan Seminar Berbasis Kooperatif Tipe Jigsawteridiri dari 3 orang dosen Jurusan Teknik Mesin FT-UNP dapat dilihat pada tabel 2 berikut:

Tabel 2. Penilaian Validator Tentang Kevalidan Isi/Materi ModulTata Tulis Karya Ilmiah dan Seminar Berbasis Kooperatif Tipe Jigsaw

\begin{tabular}{|c|c|c|c|c|c|c|c|c|c|c|c|c|}
\hline \multicolumn{13}{|c|}{ Data Validitas Materi Modul Berbasis Kooperatif Model Jigsaw } \\
\hline \multirow{3}{*}{ No } & \multirow{3}{*}{ Validator } & \multicolumn{9}{|c|}{ Item Peryantaan Angket } & \multirow{3}{*}{ Hasil Validasi } & \multirow{3}{*}{ Kategori } \\
\hline & & \multicolumn{4}{|c|}{ Kualitas Isi } & \multicolumn{5}{|c|}{$\begin{array}{c}\text { Kualitas } \\
\text { Pembelajaran }\end{array}$} & & \\
\hline & & $\mathbf{1}$ & 2 & 3 & 4 & 5 & 6 & 7 & 8 & 9 & & \\
\hline 1 & 1 & 5 & 5 & 5 & 5 & 5 & 5 & 5 & 5 & 5 & 1,00 & Valid \\
\hline 2 & 2 & 5 & 5 & 4 & 5 & 5 & 5 & 4 & 5 & 5 & 0,96 & Valid \\
\hline 3 & 3 & 5 & 5 & 5 & 4 & 5 & 5 & 4 & 5 & 5 & 0,96 & Valid \\
\hline \multicolumn{11}{|c|}{ Nilai Rata-rata Hasil Validasi } & 0,97 & Valid \\
\hline
\end{tabular}

Tabel 2. dapat disimpulkan bahwa penilaian data validasi materi modul Tata Tulis Karya Ilmiah dan Seminar Berbasis Kooperatif Tipe Jigsawdiatas diisi oleh ahli materi yaitu dosen Fakultas Teknik Jurusan Teknik Mesin yang mengampu mata kuliah Tata Tulis Karya Ilmiah dan Seminar, ke tiga validator didapat kevalidan materi/isi pada modul Tata Tulis Karya Ilmiah dan Seminar Berbasis Kooperatif Tipe Jigsawadalah 0,97 dengan kategori "valid".

\section{b. Data Uji Validasi Format Modul}

Penilaian validator tentang kevalidan format modul Tata Tulis Karya Ilmiah dan Seminar Berbasis Kooperatif Tipe Jigsaw dapat dilihat pada Tabel3.berikut:

Tabel 3. Penilaian Validator Tentang Kevalidan Format modul Tata Tulis Karya Ilmiah dan Seminar Berbasis Kooperatif Tipe Jigsaw

\begin{tabular}{|c|c|c|c|c|c|c|c|c|c|c|c|c|c|c|c|c|c|}
\hline \multicolumn{18}{|c|}{ Data Validitas Format Modul Model Kooperatif Tipe Jigsaw } \\
\hline \multirow{3}{*}{ No } & \multirow{3}{*}{$\begin{array}{c}\text { Validat } \\
\text { or }\end{array}$} & \multicolumn{14}{|c|}{ Item Peryantaan Angket } & \multirow{3}{*}{$\begin{array}{c}\text { Hasil } \\
\text { Validasi }\end{array}$} & \multirow{3}{*}{ Kategor } \\
\hline & & \multicolumn{9}{|c|}{ Aspek Format } & \multicolumn{5}{|c|}{ Aspek Bahasa } & & \\
\hline & & 1 & 2 & 3 & 4 & 5 & 6 & 7 & 8 & 9 & 1 & 2 & 3 & 4 & 5 & & \\
\hline 1 & 1 & 5 & 5 & 4 & 5 & 5 & 4 & 5 & 5 & 4 & 5 & 5 & 4 & 5 & 4 & 0,91 & Valid \\
\hline 2 & 2 & 5 & 4 & 5 & 5 & 4 & 5 & 5 & 4 & 5 & 5 & 4 & 5 & 4 & 5 & 0,91 & Valid \\
\hline 3 & 3 & 5 & 5 & 4 & 5 & 4 & 4 & 5 & 5 & 4 & 5 & 5 & 4 & 5 & 4 & 0,98 & Valid \\
\hline \multicolumn{16}{|c|}{ Nilai Rata-rata Hasil Validasi } & $\mathbf{0 , 9 3}$ & Valid \\
\hline
\end{tabular}

Tabel 3. dapat disimpulkan bahwa data validasi format modul Tata Tulis Karya Ilmiah dan Seminar Berbasis Kooperatif Tipe Jigsawdiatas diisi oleh tiga orang validator yang mengampu mata kuliah Tata Tulis Karya Ilmiah dan Seminar didapat hasil validasi penyajian 0,93 dengan kategori "Valid".

Tabel 4. Penilaian Validator Tentang Kevalidan Penyajian modul Tata Tulis Karya Ilmiah dan Seminar Berbasis Kooperatif Tipe Jigsaw

\begin{tabular}{|c|c|c|c|c|c|c|c|c|c|c|c|c|c|c|c|c|c|}
\hline \multicolumn{18}{|c|}{ Data Validitas Penyajian Modul Model Kooperatif Tipe Jigsaw } \\
\hline \multirow{3}{*}{ No } & \multirow{3}{*}{ Validator } & \multicolumn{14}{|c|}{ Item Peryantaan Angket } & \multirow{3}{*}{$\begin{array}{c}\text { Hasil } \\
\text { Validasi }\end{array}$} & \multirow{3}{*}{ Kategori } \\
\hline & & \multicolumn{4}{|c|}{ Isi } & \multicolumn{2}{|c|}{ Gambar } & \multicolumn{5}{|c|}{ Bahasa } & \multicolumn{3}{|c|}{ Tampilan } & & \\
\hline & & $\mathbf{1}$ & 2 & 3 & 4 & $\mathbf{1}$ & 2 & 1 & 2 & 3 & 4 & 5 & \begin{tabular}{|l|l}
1 \\
\end{tabular} & 2 & 3 & & \\
\hline 1 & 1 & 4 & 5 & 4 & 5 & 4 & 5 & 5 & 4 & 5 & 4 & 5 & 4 & 4 & 5 & 0,88 & Valid \\
\hline 2 & 2 & 4 & 5 & 4 & 5 & 5 & 5 & 5 & 4 & 5 & 5 & 5 & 4 & 5 & 4 & 0,91 & Valid \\
\hline 3 & 3 & 4 & 4 & 5 & 5 & 4 & 4 & 5 & 4 & 5 & 4 & 5 & 5 & 5 & 5 & 0,89 & Valid \\
\hline \multicolumn{16}{|c|}{ Nilai Rata-rata Hasil Validasi } & $\mathbf{0 , 8 9}$ & Valid \\
\hline
\end{tabular}

\section{c. Data Uji Validasi Penyajian Modul}

Penilaian validator tentang kevalidan format modul Tata Tulis Karya Ilmiah dan Seminar Berbasis Kooperatif Tipe Jigsaw dapat dilihat pada tabel 4.berikut: Data Validitas Penyajian Modul Model Kooperatif Tipe Jigsaw 
Dari tabel4 dapat disimpulkan bahwa data validasi penyajian modul Tata Tulis Karya Ilmiah dan Seminar Berbasis Kooperatif Tipe Jigsawdiatas diisi oleh tiga orang validator yang mengampu mata kuliah Tata Tulis Karya Ilmiah dan Seminar didapat hasil validasi penyajian 0,89 dengan kategori "Valid". Dari keseluruhan nilai validasi yang diberikan oleh masing-masing validator berturut-turut nilai validasi isi/materi sebesar 0,97 dengan kategori "valid", nilai validasi format modul sebesar 0,93 dengan kategori "valid", nilai validasi penyajian modul sebesar 0,89 dengan kategori "valid". Dapat diambil rata-rata validasi modul Tata Tulis Karya Ilmiah dan Seminar Berbasis Kooperatif Tipe Jigsaw yaitu 0,93 sehingga dapat disimpulkan modul tersebut masuk pada kategori "Valid". Sebagaimana terlihat pada tabel 5.berikut:

Tabel 5. Hasil Keseluruhan Validasi modul Tata Tulis Karya Ilmiah dan Seminar Berbasis Kooperatif Tipe Jigsaw

\begin{tabular}{|c|c|c|c|}
\hline No & $\begin{array}{c}\text { Data Validitas Modul Pembelajaran Model Kooperatif Tipe } \\
\text { Jigsaw }\end{array}$ & $\begin{array}{c}\text { Nilai } \\
\text { Rata-rata } \\
\% \\
\end{array}$ & Kategori \\
\hline 1 & Validitas Materi Modul model koope & 0,97 & Valid \\
\hline 2 & Validitas Format Modul model kooperatiftipe jigsaw & 0,93 & Valid \\
\hline 3 & Validitas Penyajian Modul model kooperatiftipe jigsaw & 0,89 & Valid \\
\hline \multicolumn{2}{|r|}{$\begin{array}{c}\text { Nilai Rata-rata Validitas Modul Tata Tulis Karya Ilmiah dan Seminar } \\
\text { Berbasis Kooperatif Tipe Jigsaw }\end{array}$} & $\mathbf{0 , 9 3}$ & Valid \\
\hline
\end{tabular}

\section{Data Uji Praktikalitas}

a. Respon Dosen terhadap Praktikalitas Modul PembelajaranModel KooperatifTipe Jigsaw

Praktikalitas berkaitan dengan kemudahan dalam penggunaaan modul Tata Tulis Karya Ilmiah dan Seminar Berbasis Kooperatif Tipe Jigsaw yang dikembangkan. Data praktikalitas diperoleh melalui angket yang diisi oleh seorang praktisi (Dosen mata kuliah Tata Tulis Karya Ilmiah dan Seminar) yaitu Prof. Dr. Suparno, M.Pd, dari isian angket dapat dilihat kepraktisan penggunaan modul Tata Tulis Karya Ilmiah dan Seminar Berbasis Kooperatif Tipe Jigsaw. Hasil penilaian terhadap kepraktisan modul Tata Tulis Karya Ilmiah dan Seminar Berbasis Kooperatif Tipe Jigsaw dapat dilihat pada tabel 6.berikut ini:

Tabel 6. Data Respon Dosen Tentang Praktikalitas modul Tata Tulis Karya Ilmiah dan Seminar Berbasis Kooperatif Tipe Jigsaw

\begin{tabular}{|c|l|c|c|}
\hline No & \multicolumn{1}{|c|}{ Indikator } & Nilai & Kategori \\
\hline 1 & Modul pembelajaran ini mudah digunakan sesuai dengan keinginan pengguna & 5 & $\begin{array}{c}\text { Sangat } \\
\text { Praktis }\end{array}$ \\
\hline 2 & $\begin{array}{l}\text { Penggunaan modul pembelajaran Tata Tulis Karya Ilmiah dan Seminar dapat } \\
\text { menimbulkan minat mahasiswa belajar }\end{array}$ & 5 & $\begin{array}{c}\text { Sangat } \\
\text { Praktis }\end{array}$ \\
\hline 3 & $\begin{array}{l}\text { Belajar dengan menggunakan modul pembelajaran Tata Tulis Karya Ilmiah dan } \\
\text { Seminar ini membuat mahasiswa lebih cepat memahami materi }\end{array}$ & 5 & $\begin{array}{l}\text { Sangat } \\
\text { Praktis }\end{array}$ \\
\hline 4 & $\begin{array}{l}\text { Penggunaan modul pembelajaran Tata Tulis Karya Ilmiah dan Seminar ini } \\
\text { dapat menghemat waktu dan tenaga Dosen dalam penyajian materi } \\
\text { pembelajaran }\end{array}$ & 5 & $\begin{array}{c}\text { Sangat } \\
\text { Praktis }\end{array}$ \\
\hline 5 & $\begin{array}{l}\text { Modul pembelajaran yang digunakan dapat diinterprestasikan oleh Dosen } \\
\text { Penggunaan modul Tata Tulis Karya Ilmiah dan Seminar ini dapat menjadikan } \\
\text { pembelajaran lebih menarik }\end{array}$ & 5 & $\begin{array}{l}\text { Sangat } \\
\text { Praktis }\end{array}$ \\
\hline 7 & $\begin{array}{l}\text { Modul pembelajaran Tata Tulis Karya Ilmiah dan Seminar dirancang sesuai } \\
\text { materi }\end{array}$ & 5 & $\begin{array}{l}\text { Sangat } \\
\text { Praktis } \\
\text { Praktis }\end{array}$ \\
\hline 8 & $\begin{array}{l}\text { Modul pembelajaran Tata Tulis Karya Ilmiah dan Seminar dapat digunakan } \\
\text { sebagai sarana pembelajaran mandiri }\end{array}$ & 5 & $\begin{array}{l}\text { Sangat } \\
\text { Praktis }\end{array}$ \\
\hline \multicolumn{1}{|c|}{ Jumlah Nilai Akhir } & $\mathbf{3 9}$ & \\
\hline
\end{tabular}


Praktis

Dari Tabel 6. didapat hasil uji praktikalitas modul Tata Tulis Karya Ilmiah dan Seminar Berbasis Kooperatif Tipe Jigsaw menurut dosen yaitu $97,50 \%$, sehingga dapat disimpulkan modul tersebut masuk pada kategori "Sangat Praktis".

\section{b. Respon Mahasiswa terhadap Praktikalitas Modul Tata Tulis Karya Ilmiah dan Seminar Berbasis Kooperatif Tipe Jigsaw}

Praktikalitas modul Tata Tulis Karya Ilmiah dan Seminar Berbasis Kooperatif Tipe Jigsaw juga memerlukan respon dari mahasiswa. Data ini didapatkan melalui angket yang diberikan kepada mahasiswa setelah dilakukan pembelajaran, menggunakan modul Tata Tulis Karya Ilmiah dan Seminar Berbasis Kooperatif Tipe Jigsaw. Hasil yang didapatkan sebagaimana terlihat pada tabel 7.berikut ini:

Tabel 7. Data Respon Mahasiswa Tentang Praktikalitas Modul Tata Tulis Karya Ilmiah dan Seminar Berbasis Kooperatif Tipe Jigsaw

\begin{tabular}{|c|c|c|c|}
\hline No & Aspek yang Dinilai & $\begin{array}{l}\text { Rata- } \\
\text { Rata }\end{array}$ & Keterangan \\
\hline 1. & $\begin{array}{l}\text { Dengan menggunakan modul pembelajaran model kooperatif tipe jigsaw ini } \\
\text { saya dapat mengetahui tujuan pembelajaran yang saya lakukan. }\end{array}$ & 82,42 & $\begin{array}{l}\text { Sangat } \\
\text { Praktis }\end{array}$ \\
\hline 2. & $\begin{array}{l}\text { Saya dapat belajar Tata Tulis Karya Ilmiah dan Seminar model kooperatif } \\
\text { tipe jigsaw dengan modul. }\end{array}$ & 81,21 & $\begin{array}{l}\text { Sangat } \\
\text { Praktis }\end{array}$ \\
\hline 3. & $\begin{array}{l}\text { Dengan menggunakan modul model kooperatif tipe jigsaw dapat membantu } \\
\text { saya belajar secara mandiri. }\end{array}$ & 84,24 & $\begin{array}{l}\text { Sangat } \\
\text { Praktis }\end{array}$ \\
\hline 4. & $\begin{array}{l}\text { Saya mudah mengguanakan modul pembelajaran model kooperatif tipe } \\
\text { jigsaw ini }\end{array}$ & 78,18 & $\begin{array}{l}\text { Sangat } \\
\text { Praktis }\end{array}$ \\
\hline 5. & $\begin{array}{l}\text { Penjelasan/gambar/tabel yang ada pada modul dapat membuat saya lebih } \\
\text { mudah memahami konsep kegiatan pembelajaran. }\end{array}$ & 83,64 & $\begin{array}{l}\text { Sangat } \\
\text { Praktis }\end{array}$ \\
\hline 6. & $\begin{array}{l}\text { Saya mudah membaca teks dan kalimat yang ada pada modul pembelajaran } \\
\text { Tata Tulis Karya Ilmiah dan Seminar model kooperatif tipe jigsaw ini }\end{array}$ & 79,39 & $\begin{array}{l}\text { Sangat } \\
\text { Praktis }\end{array}$ \\
\hline 7. & $\begin{array}{l}\text { Saya mudah memahami bahasa yang digunakan dalam modul pembelajaran } \\
\text { Tata Tulis Karya Ilmiah dan Seminar model kooperatif tipe jigsaw ini. }\end{array}$ & 80,00 & $\begin{array}{l}\text { Sangat } \\
\text { Praktis }\end{array}$ \\
\hline 8. & Modul model kooperatif tipe jigsaw dirancang sesuai materi. & 81,21 & $\begin{array}{l}\text { Sangat } \\
\text { Praktis }\end{array}$ \\
\hline 9. & $\begin{array}{l}\text { Modul model kooperatif tipe jigsaw yang dikembangkan dapat } \\
\text { meningkatkan penalaran saya untuk memahami materi pembelajaran }\end{array}$ & 83,64 & $\begin{array}{l}\text { Sangat } \\
\text { Praktis }\end{array}$ \\
\hline 10. & $\begin{array}{l}\text { Modul pembelajaran model kooperatif tipe jigsaw ini membantu saya } \\
\text { mempermudah untuk memahami materi Tata Tulis Karya Ilmiah dan } \\
\text { Seminar. }\end{array}$ & 80,00 & $\begin{array}{l}\text { Sangat } \\
\text { Praktis }\end{array}$ \\
\hline 11. & $\begin{array}{l}\text { Modul pembelajaran model kooperatif tipe jigsaw ini memotivasi saya } \\
\text { untuk belajar Tata Tulis Karya Ilmiah dan Seminar. }\end{array}$ & 79,39 & $\begin{array}{l}\text { Sangat } \\
\text { Praktis }\end{array}$ \\
\hline 12. & $\begin{array}{l}\text { Modul pembelajaran model kooperatif tipe jigsaw ini menarik minat saya } \\
\text { untuk belajar Tata Tulis Karya Ilmiah dan Seminar. }\end{array}$ & 80,00 & $\begin{array}{l}\text { Sangat } \\
\text { Praktis }\end{array}$ \\
\hline 13. & $\begin{array}{l}\text { Modul pembelajaran model kooperatif tipe jigsaw ini membuat saya lebih } \\
\text { aktif dalam belajar }\end{array}$ & 81,21 & $\begin{array}{l}\text { Sangat } \\
\text { Praktis }\end{array}$ \\
\hline & Presentase $\mathbf{P}$ & 81,12 & $\begin{array}{l}\text { Sangat } \\
\text { Praktis }\end{array}$ \\
\hline
\end{tabular}

Dari Tabel 7.didapat rata-rata hasil uji praktikalitas modul model kooperatiftipe jigsaw menurut mahasiswa yaitu $81,12 \%$, sehingga dapat disimpulkan modul tersebut masuk pada kategori "Sangat Praktis".

\section{Data Uji Efektifitas}

Data hasil belajar diambil bertujuan untuk melihat hasil belajar mahasiswa sesudah menggunakan modul model kooperatiftipe jigsaw pada mata kuliah Tata Tulis Karya Ilmiah dan Seminar. Hasil belajar didapat setelah dilakukan tes pretestdanpostestdengan menggunakan soal berbentuk pilihan ganda sebanyak 44 buah soal..Hasil yang didapatkan sebagaimana terlihat pada tabel 8.berikut ini: 
Tabel 8. Data Jasil Pretest dan Postest Hasil Belajar Mahasiswa Kelas Kontrol (Konvensional Ceramah) dan Kelas Eksperimen(Modul PembelajaranModel KooperatifTipe Jigsaw)

\begin{tabular}{|c|c|c|c|c|c|}
\hline No & Penelitian & $\begin{array}{c}\text { Jumlah Betul } \\
\text { Rata-rata } \\
\text { Pretest }\end{array}$ & $\begin{array}{c}\text { Nilai Rata-Rata } \\
\text { Pretest }\end{array}$ & $\begin{array}{c}\text { Jumlah } \\
\text { Betul } \\
\text { Rata-rata } \\
\text { Postest }\end{array}$ & $\begin{array}{c}\text { Nilai } \\
\text { Rata-Rata } \\
\text { Postest }\end{array}$ \\
\hline 1 & Kelas Kontrol & $\mathbf{2 1 , 5}$ & $\mathbf{4 8 , 7 7}$ & $\mathbf{2 7 , 6}$ & $\mathbf{6 2 , 7 3}$ \\
\hline 2 & $\begin{array}{c}\text { Kelas } \\
\text { Eksperimen }\end{array}$ & $\mathbf{2 1 , 6 6}$ & $\mathbf{4 9 , 2 2}$ & $\mathbf{3 5 , 6 6}$ & $\mathbf{8 1 , 0 4}$ \\
\hline
\end{tabular}

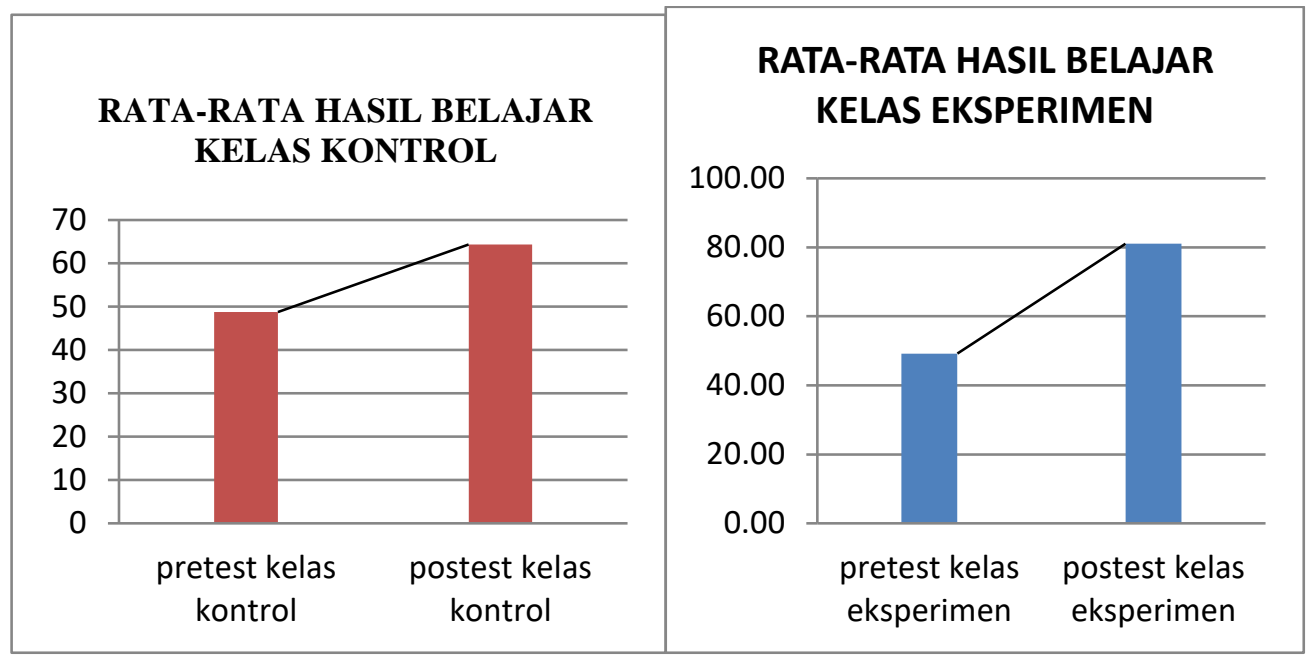

Gambar 3. Histogram Peningkatan Nilai Hasil Belajar Mahasiswa Kelas Kontrol dan Kelas Eksperimen

Dari data tersebut, diperoleh rata-rata hasil belajar atau pretestpada kelas kontrol tidak menggunakan modul sebesar 48,77 dan rata-rata hasil belajar mahasiswa setelah menggunakan metode pembelajaran konvesional ceramah sebesar 62,73.

Rata-rata hasil belajar atau pretestkelas eksperimen sebelum menggunakan modul sebesar 49,22 dan rata-rata hasil belajar mahasiswa setelah menggunakan modul pembelajaranmodel kooperatiftipe jigsaw sebesar 81,04.

Melihat peningkatan rata-rata hasil belajar mahasiswa sesudah menggunakan modul pembelajaran model kooperatiftipe jigsaw, dapat disimpulkan bahwa penggunaan modul pembelajaran model kooperatiftipe jigsaw ini efektif untuk meningkatkan hasil belajar, dibuktikan dengan meningkatnya rata-rata hasil belajar mahasiswa Program Studi D3 Teknik Mesin yang mengambil mata kuliah Tata Tulis Karya Ilmiah dan Seminar.

\section{V.Kesimpulan}

Berdasarkan hasil penelitian pengembanganmodul yang telah dilakukan, maka diperoleh kesimpulan sebagai berikut:

1. Penelitian pengembangan modul Tata Tulis Karya Ilmiah dan Seminar Berbasis Kooperatif Tipe Jigsaw dikembangkan dengan menggunakan model IDI, yang terdiri dari tahap pendefinisian (define), pengembangan (develop) dan evaluasi (evaluate). modul Tata Tulis Karya Ilmiah dan Seminar Berbasis Kooperatif Tipe Jigsaw terdiri dari 8 kegiatan kuliah yang disesuaikan dengan sinopsis dan SAP Tata Tulis Karya Ilmiah dan Seminar. Masing-masing kegiatan kuliah terdiri dari indikator tujuan kegiatan perkuliahan, uraian materi, rangkuman, tes formatif, soal latihan, lembaran kerja mahasiswa dan jawaban tes formatif. Latihan pada setiap kegiatan kuliah terdiri atas latihan tes formatif dengan jumlah soal sebanyak 5 butir untuk soal objebtif dan 5 butir soal essay.

2. Validitas modul Tata Tulis Karya Ilmiah dan Seminar Berbasis Kooperatif Tipe Jigsaw pada aspek materi di dalam modul di dapat rata-rata hasil validasi adalah 0,97 dengan kategori "valid", pada aspek format didalam modul di dapat rata-rata hasil validasi adalah 0,93 dengan 
kategori "valid", pada aspek penyajian didalam modul di dapat rata-rata hasil validasi adalah 0,89 dengan kategori "valid", Rata-rata hasil modul Tata Tulis Karya Ilmiah dan Seminar Berbasis Kooperatif Tipe Jigsaw yaitu 0,93 sehingga dapat disimpulkan modul tersebut masuk pada kategori "Valid". Praktikalitas modul dalam pembelajaran dapat dilihat dari keterlaksanaan penggunaan modul Tata Tulis Karya Ilmiah dan Seminar Berbasis Kooperatif Tipe Jigsaw secara keseluruhan dengan baik. Ini terlihat dari hasil respon dosen yang memperoleh persentase rata-rata $97,50 \%$ dan hasil respon mahasiswa yang memperoleh persentase rata-rata $81,12 \%$. Hal ini menunjukkan modul Tata Tulis Karya Ilmiah dan Seminar Berbasis Kooperatif Tipe Jigsaw yang dikembangkan termasuk pada kategori "sangat praktis". Efektivitas modul yang dikembangkan terhadap mahasiswa dilihat dari lebih tingginya nilai rata-rata kelas eksperimen dari kelas control.

\section{Referensi}

A. Pribadi, Benny. (2009). Model Desain Sistem Pembelajaran. Jakarta: PT Dian Rakyat.

Arends 1997. Model-Model Pembelajaran Inovatif berorientasi Konstuktivitis, Jakarta:Prestasi Pustaka Publisher

Djamarah, Bahri, Syaiful dan Zain, Aswan. 2010. Strategi Belajar Mengajar. Jakarta: Rineka Cipta.

E. Mulyasa. 2005. Kurikulum Berbasis Kompetensi. Konsep, Karakteristik, Implementasi Dan Inovasi. Bandung: PT. Remaja Rosdakarya.

Lie, Anita. 2002. Kooperatif : mempraktikkan kooperatif diruang-ruang kelas, Jakarta: Grasindo

Nasution. 2003. Metode Research, Jakarta : PT. Bumi Aksara

Sugiyono. 2011. Metode Penelitian Kuantitatif, Kualitatif dan $R \& D$. Bandung: Alfabeta.

Syaiful Sagala. 2003. Konsep dan Makna Pembelajaran. Bandung: Alfabeta.

Tortora, G.R. and Rabowski,S.H.,2003, Principles of anatomy and physyology, John wiley \& Sons. Inc, US 